\title{
東京都区部にお打る発生・吸収交通に関する研究 (第一報)*
}

\section{奥野 隆 史**}

\begin{abstract}
摘要 従来の地理学における都市交通研究はおもに量的面からその地域性を論じているが, 質的面からの 研究は通勤交通を除いては少ないように思われる。また, 都市交通の地域性の要因である都市構成と都市交 通が別個に取り扱われている場合が多い，筆者は都市構成と関連付けながら都市交通の地域性を量的面ばか りでなく質的面からも考察しようと試みた。発生交通の量的・質的の地城性, それと人口・土地利用との関 係, 発生交通の指向性の三つを問題として取り上げ, 東京都区部を対象地域として摘出した小学校区域に調 査票を配布し，それから得られた資料を整理して上記の問題についてまとめた。
\end{abstract}

\section{I. 従来の研究と問題の所在}

19 世紀以来, 近代都市の発達とと为に発生，発展 してきた都市内の交通問題は，大都市が過大化する につれて都市問題研究のうち非常に重要な比重を占 めるに至った(122334)。この都市交通の従来の研究を 概観するとだいたい三つの面がある。すなわち，(1) 過大都市の交通混乱を問題とする政策的面，(2)その 政策を具体化しょうとする計画的面，(3)それらの基
礎となる交通実態を把握しょうとする実証的面であ る. (1)については都市行政を始めとして都市に関心 を寄せている諸分野から576778)，(2)については土木 工学，都市計画，交通学などから研究されてい る910011112).(3)については都市地理, 都市社会, 都 市計画などの諸分野から研究がなされており13314115) 16)，そのうち地理学の分野においては (A) Dickinson,

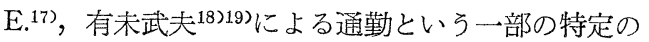
種類の都市交通の地域性についての研究，(B) COHEN，

* 本報は学位論文の一部分をまとめたものである。

** 東京教育大学地理学教室, Dept. of Geog., Fac. of Science, Tokyo kyôiku Univ.

1) Munford, L. (1938) : The Culture of Cities, p. 410

2) Taylor, G. (1949) : Urban Geography, p. 173

3) Houston, M. J. (1953) : The Social Geography of Europe, p. 152

4) Gilmore, W. H. (1953) : The Transportation and Growth of City, p. 108

5) Maybury, H. (1925) : Traffic Problems in Great Cities, Municipal Journal and Public Works Engineer, $34 \quad 1103 \sim 1104$

6) Schwanter, R. (1928) : Probleme der großstädtischen Verkehrswesens, Verkehrstechnik, 19 S. 212

7) Childe, V. (1950) : The Urban Revolution, Town Planning Rev., 21 78-96

8）金谷重義（1955）：大都市圈の交通問題，都市問題研究 $7 \quad 34-45$

9) Raper, C. (1936) : Transportation and Economic Planning, Annals, 187 7-15

10) Mitchell, B. \& Rapkin, C. (1954) : Urban Traffic, p. 5

11) Casey, J. (1956) : Integrated Transportation Program, Traffic Quarterly, 10 416-427

12）高山英華（1959）：都市計画よりみた大都市圈調查について，都市問題５0５9-67

13) Mackinnon, L. (1935) : Public Road Passenger Transport, Modern Transport, 13311

14) Iklé, F. (1954) : Sociological Relationship of Traffic to Population and Distance, Traffic Quarterly, 18 $123-136$

15），角本良平（1956）：都市交通一その現状と対策，174

16) Higasa, T.(1960) : A Study of the Planning Unit and the Organisation of Facilities of the Residential Area，建築研究報告，32 1-65

17) Dickinson, E. (1957) : The Geography of Commuting : The Netherland and Belgium, Geog. Rev., 47 $521-538$

18）有末武夫（1950）関東地方の通勤交通，地理評 23 175-181

19）有末武夫（1950）東京の通勤交通，地理評 23 367-373 
B. \& Applebaum, W. ${ }^{20)}$, 清水馨八郎 ${ }^{21222}$ などの交 通需要から都市交通を分析しょうとした研究，(C)都 市交通を都市構造の一面としてその地域性を考察し

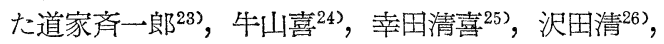
有未武夫27288などの諸研究，という三つの種類があ; るように思われる。

これら從来の地理学における都市交通研究はおも に量的面からその地域性を論じているが，質的面か らの研究は通勤交通を除いては比較的少ない。また 都市交通の地域性の要因である都市構成々都市交通 が別個に限り扱われている場合が多い，そこで，筆 者は都市構成と関連付けながら都市交通の地域性を 量的面ばかりでなく質的面からも教察しょうと試み た29).

都市交通現象は，ある地点からある目的をもって 発生し，ある路を通って，他の地点に到達しその目 的を果たしてその現象は終了する.したがって，こ の現象は交通が発生する場所, 通過する路, 吸収さ れる場所抢よび交通目的の 4 要素にわけられる。 そ のうち，通過する路は発生する場所と吸收される場 所の分布状態によって定められるので，発生地域， 吸収地域，交通目的の 3 点加ら都方交通の地域性を 分析し得よう。これに関係をもつ都市構成について
は，竫戌市に打ける研究結果から人口と土地利用の 二つを取り上げだ30.

上述の目的と方法において問題点をいくつかあげ るとつぎのようである.

（1）地域加発生する交通（発生交通）の量的・ 質的の地域性

（2）その地域性と人口・土地利用との関係

（3） 発生交通の指向性

（4）地域に吸収される交通（吸収交通）の量的・ 質的の地域性

(5) その地域性と前記 2 要䓇の都市構成との関係 これら以外に为種々の問題があるが，等者は上記 の間題点を中心として研究を行なった．今回はその うち(1)(2)(3)老中心として報告する.

研究の対象地域は東京都区部走選んだ，それは本 邦に执いては東京が交通の質的面において最り多様 性にとみ，都市構成の地域分化が非常に顕著である ので，都市交通と都市構成との関係を乡明確にする のに便利であると思われるからである。

\section{II. 調 查 法}

上記の問題に関して自動車交通を調查する方法で ある $\mathrm{O}-\mathrm{D}$ 調査，すなわち起終点調查の方法を利用

20) Cohen, B. \& Applebaum, W. (1960) : Evaluating Store Sites and Determing Store Rents, Econ. Geog., $36 \quad 1-35$

21）清水馨八郎 (1954)：大都市交通量の偏倚と都心の人口吸収力一大都市交通問題とその対策に関する一試 案, 地理評, $27416-428$

22）清水謷八郎（1955）：大都市の交通量と㡺・夜閒人口との関係一首都交通問題とその対策の砳究，地理評， $28 \quad 577-589$

23）道家斉一郎（1926）：統計より見たる東京市の交通，地理評，2 811

24）牛山喜（1934）: 大都市乗車交通論より観たる東京市の地域性，大塚地理学会論文集 3 集 201一258

25）幸田清喜・沢田清（1951）：都市内域の交通流，地理評，24 65-72

26）沢田清（1955）：名古屋の交通流一市外垉域より市内地域に流入する旅客交通量より，金沢大学教育学部 紀要, 3 18-32

27）有末武夫 (1960)：東京およびその周辺に抢ける交通量の推移，群馬大紀要人文科学篇 $11 \quad 1$-9

28）有末武夫 (1962)：京葉工業地带の道路交通，人文地理，14 25-38

29）このことは Mitchell, B.・Rapkin, C. 抗よび Row, T. は都市交通研究にとって不可欠なテーマであると 指摘しているが，何ら具体的な研究を行なっていない. Mitchell, B. \& Rapkin, C. (1954) : 前揭 10)， Row, T. (1955) : An Approach to O-D Data Analysis, Traffic Quarterly, 9 115--122

30）奥野隆史（1957）：静岡市に打ける都市域の交通，1957 年 10 月日本地理学会例会発表。 
第 1 表 調 查 票

\section{東京都 民の外出調 查}

との調植は学術研究のためのものですからとの調查票をらけ取つた生徒はよく読んでくわしく書いて下さい

1）下の表に生徒は自分の住所・氏名及び家族についての事柄を害き入れて下さい

\begin{tabular}{|c|c|c|c|c|c|c|c|}
\hline 住 & 亲 & 区 & 町 & 番地 & 家族の氏名 & 年 令 & 職業（会社貣の場合仗会社名とできるた゚けくかしく） \\
\hline \multicolumn{8}{|l|}{ 氏 } \\
\hline & & & & & & & \\
\hline & & & & & & & \\
\hline & & & & & & & \\
\hline & & & & & & & \\
\hline
\end{tabular}

2）市なたの家で7月15日（激雨注意予報が出た場合は次の日）に外出した家族から生徒が聞いてそれぞれ下の注意を㜔んで下の表に書き 入れで下さい。

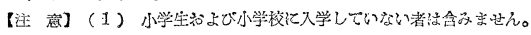

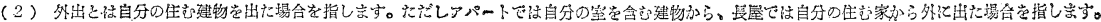

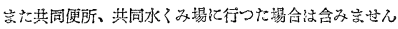

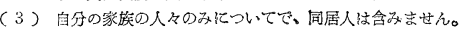

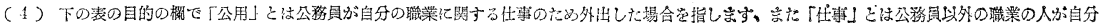

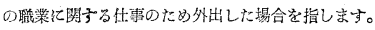

[一例]山田太郎され(公務員が朝 8 時半頃国電で自宅新宿区百人町) から都庁（千代田区丸の内）に通勤し勤奻が終つた後、夕方 5 時 頃日比谷映画劇場（千代田区有楽町）に映西を見に行き、それが終つて皮りました。この揚合は下の表のように書き入れます。

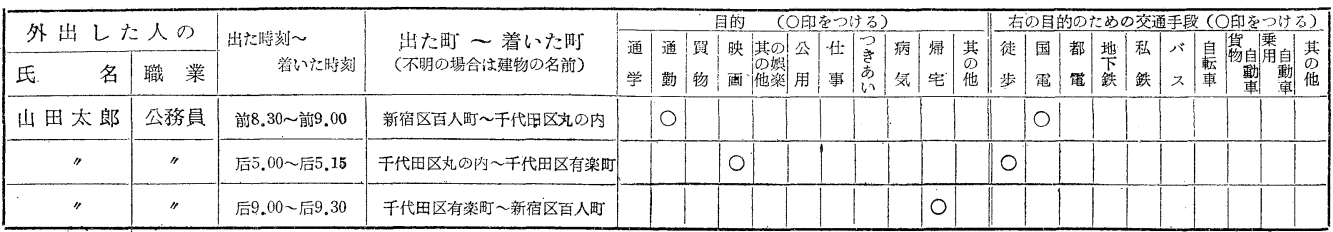

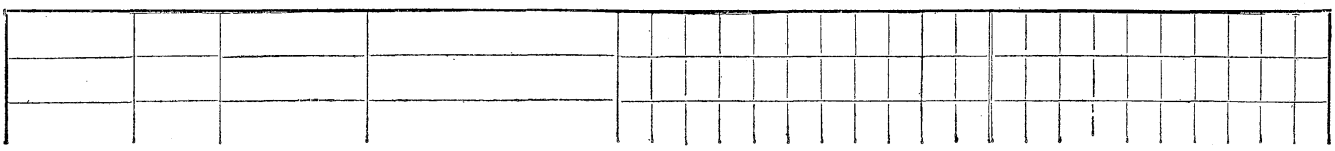

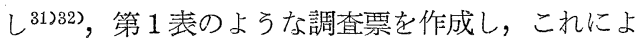

って資料を獲得することにした ${ }^{333}$.

この調查票を東京都の全世萜に配布することは個

人的には不可能に近いのでこえを小学校を通じて

その生徒の家庭に配布し，中学生以上の人に関する

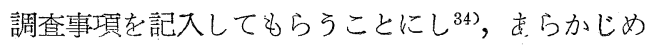
各学校の教師に票の記入法について徹底的に生徒走 指導するよう依頼した ${ }^{35)}$. これは回収率を高めるこ

31) Robert, D. (1953): A Modified O and D Survey, Traffic Quarterly, 7 261-272

32) Melvin, A. \& Sherwood, H. (1954) : Surveys in Miami show Stability of O-D Patterns, Traffic Quarterly, $8 \quad 454-471$

33）従来の都市交通の既在の調查資料については外部調查法によるものが多く，これは交通の量的把握に重 点がおかれている．交通の発生・到達地点を調查しているものには，建設省 (1958)：起終点都市交通調査 報告書，東京都（1958）：乗客交通調查集計書，運輸省（1960）：大都市交通センサス などあるが，これ らにおいても交通目的に関しては調查していない。

34）次章以下の調查票に基づいた数量は中学生以上の人に関するものである。

35）「通勤」と「任事」は混用しやすいので，前者は住所と働く場所が分離している場合の交通であり，後者 は有業・無業者いずれの場合でも自分の職業に関する仕事のための交通であることを特に指導するよう依 頼した。 
とと記入精应を高めることを目的としたからである。 このようにしたので，単位地域は小学校学区域とな り，後述のすべての資料はこの学区域単位である.

この場合，1学区域における悉皆調査と同程度の 結果を得るのには調査票数をどの程度にすればよい かを検討する必要があるので，筆者は静岡県下田町 においてその検討を行なった，その結果，1学区域 を単位地域とするならば(下田町の場合, 約 2,000 世
带, 人口約 8,000 の大きさ), 小学校の 1 学級老対象 としてその家庭に調査票を配布すればよいとの結果 を得た ${ }^{36)}$. 東京都に抢ける 1 学区域の大きさと下田 町のそれとは著しい差があるとは認められない。し たがって，下田町の経渿的・社会的性格と東京都の それとは異なるが，東京都に㨟いて1学級を摘出集 団として取るならば，それと母集団である 1 学区域 全数との適合性も下田町と同様により有意であると

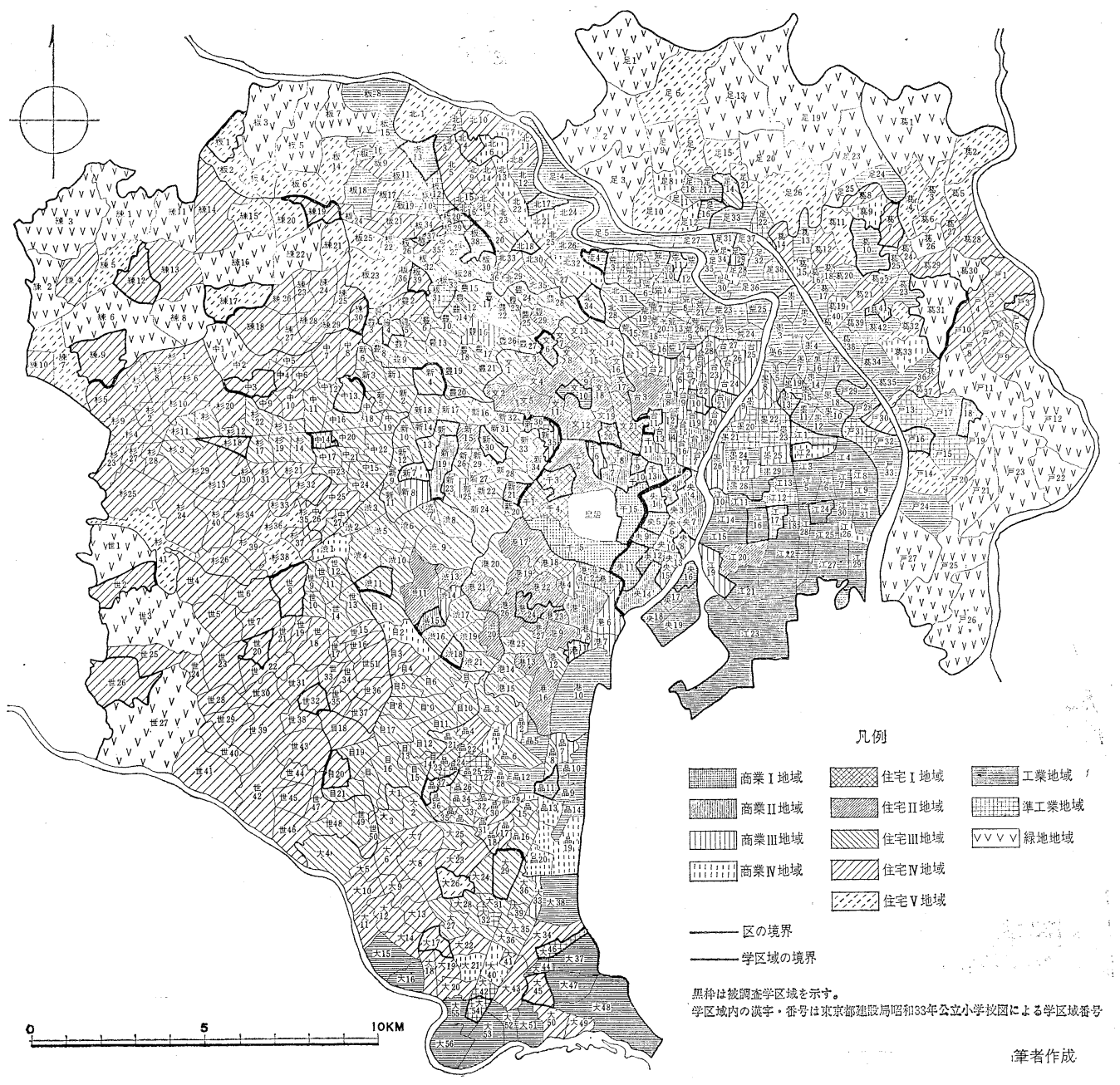

第 1 図 東京都区部に打ける地域区分と被調查学区域

36） 1 学区域に扣ける母集団と小学校の 1 学区域を選んだ摘出集団との産業別人口横成比に打ける適合性を 自由度 8 のカイ自乗法によって求めると，95\%の信頼度でより有意であることが明らかになった。 
いえる.したがって，1学区域につき小学校 1 学級 の生徒の家庭に調查票を配布する方法在とった。

東京都区部に怙ける733 学区域在都市訫画用途別 地域図によって商業・住宅・工業・準工業・緑地の 5 種の地域に分類し，さらに固定資産税評価価格図 によって商業地域を 4 種, 住宅地域を 5 種の地域に 細分して733 学区域を 12 地域に区分した。この分 類した学区域から第 1 図で示すように 85 の被調査 学区域を選定した．その選定に際してはつぎのこと に留意した、すなわち，（i）同分類の学区域がかなり まとまっている地域からその地域を代表するものと して若干の学区域を選定する。住宅地域の場合はま とまっている地域内ではそれ程大きな地域差が認め られるとは思われないのだ，まとまった地域から 1 学区域を選び，商業地域の場合はかなり地域差が認 められると思われるので一特に都心の場合一，2，3 の学区域を選ぶ.（ii）周辺の学区域と異なる地域性 在もつ孤立しているよう度学区域は選定する。(iii) できるだけ被調查学区域が東京都区部全域にちらば るように選定する.

85 学区域の小学校 6 学年の 1 学級に 50 枚ずつ, 計 4, 250 枚の票を配布した. 回収数は 3,522 , 有效数は 3,205 でこれ は東京都区部の母集団約 145 万世带の $0.22 \%$ に当たる.

上記のように選定した 85 学区域は， その周辺の諸学区域莡代表しているので， それらに配布した調查票から得られる資 料は 733 学区域に調查票在配布して得ら れる資料と同じょうな傾同性をもつもの と考えられる.したがって，筆者は次章 以下に掠いてはこの 85 学区域に調査票 を配布して得た資料に基づいて論をすす。 めることにした。

\section{III. 発生交通の地域性と都市構成己の関係}

\section{1）発生交通量と人口乞の関係}

調查票から外出した回数を学区域別に集計し，そ れを学区域の発生交通量とした.この際，1回の外 出で目的を複数にもったものは目的每に数えること にした.すなわち，1回の外出である地点で目的な 果たし，またある地点で他の目的を果たした場合， 発生交通量は 2 回であるように数えた。したがって， この際の交通量とは交通回数の意味であり，以下交 通量に関することは同様である。この発生交通量は 各学区域によって異なるが，最初に人口との関係を 考察する.

第 2 図は発生交通量と人口との関係をみるために 作成したものである、縱軸に発生交通量, 横軸に人 口数茊取ってプロットすると両者の相関係数妵 0.87 で，関係近似式は $y=0.91 x$ となり，発生交通量と 人口数との間にかなり密接な関係があることが明ら かになった，そこで，各学区域每の 1 人当たりの発

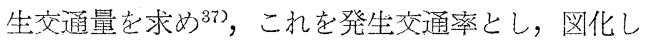

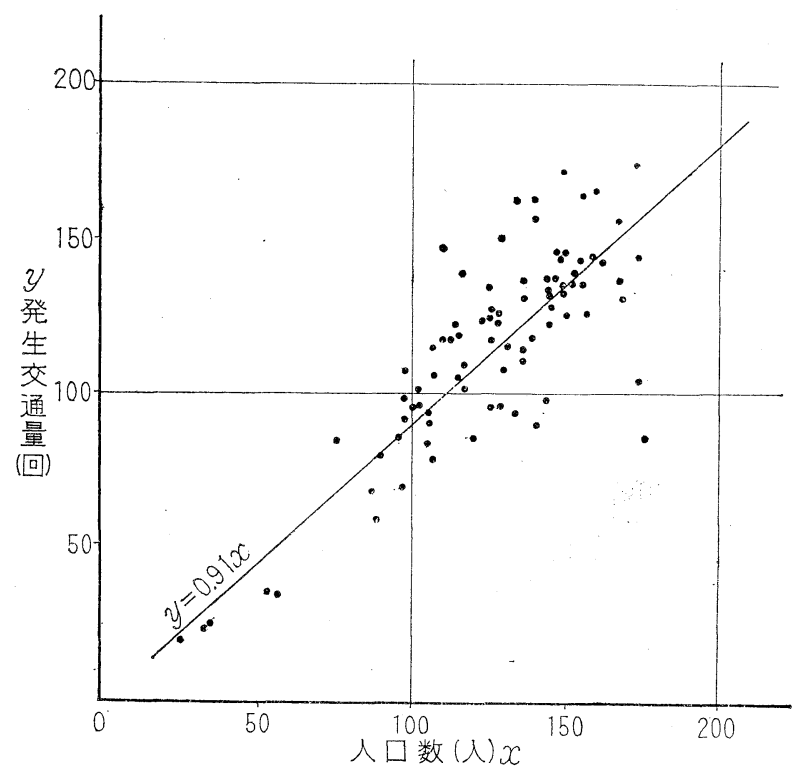

第 2 図 発生交通量と人口との関係

37）各学区域の発生交通量を各学区域の調查票に記入された中学生以上の人口で除したもの。 


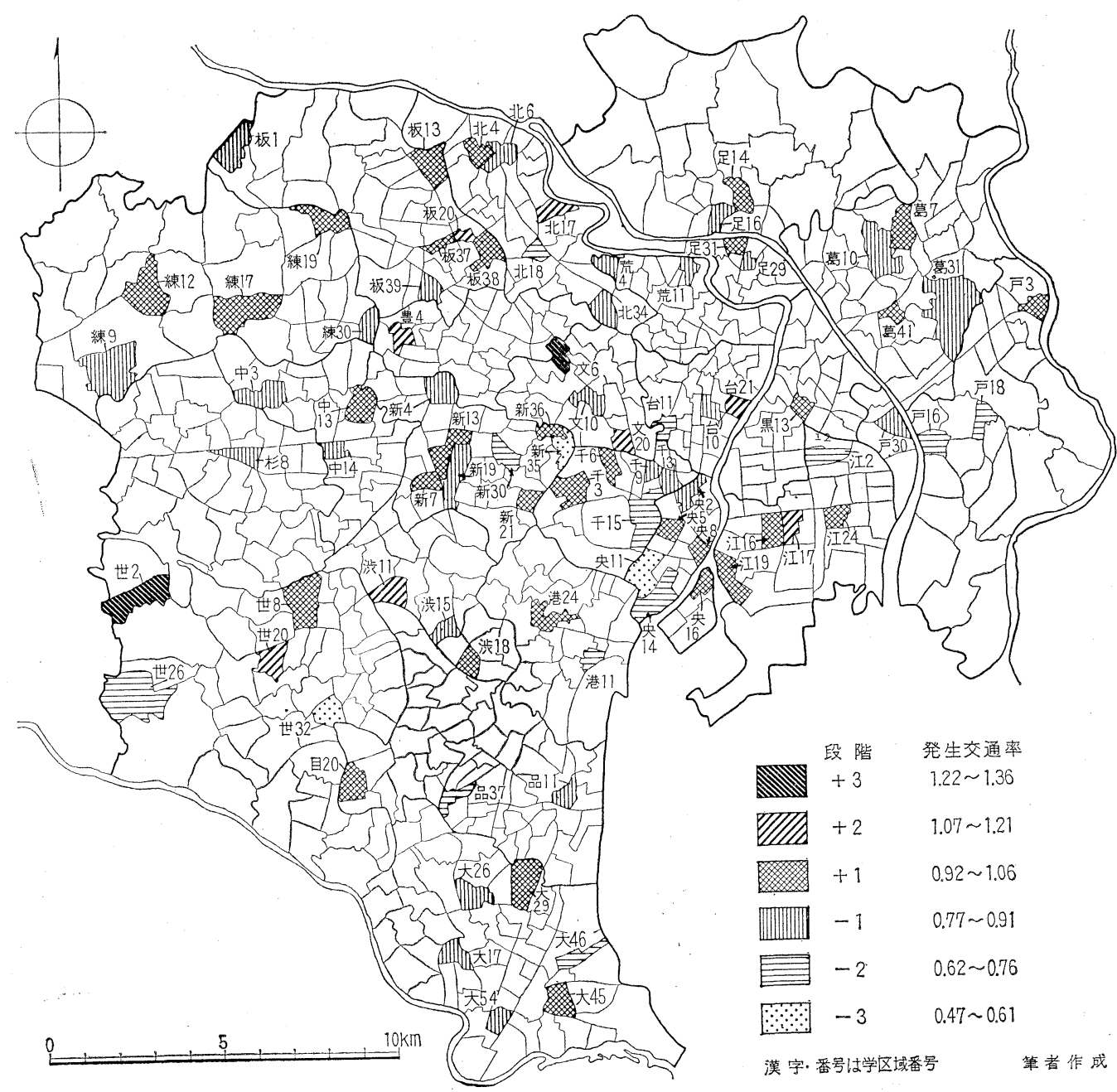

第 3 図 東京都区部の被調查学区域に招ける発生交通率の分布

たのが第 3 図である。この図は学区域別に発生交通 率を計算し, 85 学区域のそれの算術平均值 $\bar{x}=0.91$, 標準偏差值 $\sigma=0.15$ 在求め, 各区域の発生交通率 を $x_{i}$ とし， $\bar{x} \leqq x_{i}<\bar{x}+\sigma$ の場合を段階 $+1, \bar{x}+\sigma$ $\leqq x_{i}<\bar{x}+2 \sigma$ の場合在段階 $+2, \bar{x}+2 \sigma \leqq x_{i}<\bar{x}+3 \sigma^{-}$ の場合を段階 $+3, \bar{x}>x_{i} \geqq \bar{x}-\sigma$ の場合を段階 -1 , $\bar{x}-\sigma>x_{i} \geqq \bar{x}-2 \sigma$ の場合を段階 $-2, \bar{x}-2 \sigma>x_{i} \geqq$ $\bar{x}-3 \sigma$ の場合を段階 -3 のように 6 段階を設定し て色別したものである。

85 学区域の発生交通率の頻度分布はだいたい正
規分布になるので， $+1,-1$ の段階の地域は標準的 な発生交通率をも一学区域と考えられる。

$+3,+2$ の段階の学区域は文京・ 6 , 世田谷・2, 文京・ 20 , 台東・ 21 , 江東・ 17 , 世田谷・ 20 , 涉谷・ 11，豊島・4，北・17，板橋・20の 10 学区域であり， これらはいずれも都心の周辺地域に在在している。

$-3 ，-2$ の段階の発生交通率の低い学区域は中 央 $\cdot 11$, 新宿 $\cdot 35$, 世田谷・ 32 ，千代田・ 15 ，中央 $・$ 14, 港・ 11 ，新宿 $\cdot 30$ ，台東・ 11 , 江東 - 2 , 品川・ 37 ，大田・46，世田谷・ $26 ，$ 北・ 18 ，江戸川・16・ 
第 2 表 東京都区部の摘出学区域における産業別の発生交通率と段階

(昭和 33 年)

\begin{tabular}{|c|c|c|c|c|c|c|}
\hline & 全 & 製造業 者 & 卸・ 小売業者 & サービス業者 & 公務・自由業者 & 無 業 者 \\
\hline 文 京・ 6 & $1.23(+3)$ & $1.42(+4)$ & $0.91(-2)$ & $2.00(+4)$ & $1.55(+2)$ & $1.17(+12)$ \\
\hline 世田谷・ 2 & $1.23(+3)$ & $1.10(+1)$ & $1.50(+4)$ & $1.50(+2)$ & $1.11(-1)$ & $1.15(+12)$ \\
\hline 文 京・2J & $1.16(+2)$ & $1.39(+4)$ & $1.58(+4)$ & $0.89(-1)$ & $1.00(-1)$ & $1.02(+7)$ \\
\hline 台 東・21 & $1.13(+2)$ & $1.56(+5)$ & 1. $26(+2)$ & $0.83(-1)$ & $1.00(-1)$ & $1.06(+9)$ \\
\hline 江 東・ 17 & $1.14(+2)$ & $0.86(-3)$ & $1.31(+2)$ & $1.45(+2)$ & $1.75(+2)$ & $1.14(+11)$ \\
\hline 世田谷・20 & $1.16(+2)$ & $1.23(+2)$ & $1.11(+1)$ & $0.78(-1)$ & $1.54(+2)$ & $1.23(+14)$ \\
\hline 混 谷・11 & $1.21(+2)$ & $1.14(+1)$ & $1.17(+1)$ & $1.50(+2)$ & $0.67(-2)$ & $1.23(+14)$ \\
\hline 橭 島・ 4 & $1.10(+2)$ & $1.53(+5)$ & $1.50(+4)$ & $0.69(-1)$ & $1.14(-1)$ & $0.95(+5)$ \\
\hline 北 $\cdot 17$ & $1.07(+2)$ & $1.14(+1)$ & $0.80(-3)$ & $0.82(-1)$ & $4.00(+10)$ 注 $)$ & $1.13(+11)$ \\
\hline 板 橋・ 20 & $1.07(+2)$ & $1.54(+5)$ & $2.25(+10)$ & $0.67(-2)$ & $1.11(-1)$ & $0.92(+4)$ \\
\hline 中 央 $\cdot 11$ & $0.60(-3)$ & & $0.87(-2)$ & $1.40(+2)$ & & $0.48(-12)$ \\
\hline 新 宿・ 35 & $0.48(-3)$ & $0.35(-8)$ & $0.42(-6)$ & $0.38(-3)$ & $0.60(-2)$ & $0.54(-10)$ \\
\hline 世田谷・32 & $0.59(-3)$ & $0.64(-5)$ & $0.77(-3)$ & $1.00(+1)$ & $1.40(+1)$ & $0.39(-15)$ \\
\hline 千代田・15 & $0.70(-2)$ & $0.90(-1)$ & $0.75(-3)$ & $0.60(-2)$ & $1.00(-1)$ & $0.65(-6)$ \\
\hline 中 央 14 & $0.68(-2)$ & $0.63(-5)$ & $0.69(-3)$ & $1.00(+1)$ & $1.33(+1)$ & $0.52(-10)$ \\
\hline 港 ・11 & $0.70(-2)$ & $0.74(-4)$ & $0.79(-3)$ & $0.38(-2)$ & $1.50(+1)$ & $0.67(-5)$ \\
\hline 新＼cjkstart宿・30 & $0.73(-2)$ & $0.67(-5)$ & $0.80(-3)$ & $0.50(-2)$ & $1.00(-1)$ & $0.70(-4)$ \\
\hline 台 東 $\cdot 11$ & $0.65(-2)$ & $0.43(-7)$ & $0.69(-3)$ & $0.33(-3)$ & $0.00(-4)$ & $0.77(-2)$ \\
\hline 江 東 2 & $0.73(-2)$ & $1.25(+2)$ & $0.88(-2)$ & $0.30(-3)$ & $1.33(+1)$ & $0.55(-9)$ \\
\hline 品 川・37 & $0.76(-2)$ & $1.00(-1)$ & $0.50(-5)$ & $1.50(+2)$ & & $0.63(-7)$ \\
\hline 大 田・ 46 & $0.66(-2)$ & $0.50(-6)$ & $0.50(-5)$ & $1.33(+2)$ & $1.50(+1)$ & $0.64(-6)$ \\
\hline 世田谷・ 26 & $0.70(-2)$ & $1.67(+6)$ & $1.00(-1)$ & & $1.00(-1)$ & $0.43(-13)$ \\
\hline 北 $\cdot 18$ & $0.71(-2)$ & $0.74(-4)$ & $0.80(-3)$ & $1.00(+1)$ & $1.20(+1)$ & $0.56(-9)$ \\
\hline 江戸川・16 & $0.63(-2)$ & $0.77(-4)$ & $0.46(-5)$ & $1.00(+1)$ & $0.67(-2)$ & $0.49(-11)$ \\
\hline$" \prime \cdot 18$ & $0.73(-2)$ & $0.92(-2)$ & $0.72(-3)$ & $0.67(-2)$ & $0.00(-4)$ & $0.70(-4)$ \\
\hline 平 均 值 & 0.91 & 1.07 & 1.07 & 0.98 & 1.19 & 0.81 \\
\hline 標準偏差値 & 0.15 & 0.10 & 0.13 & 0.31 & 0.31 & 0.03 \\
\hline
\end{tabular}

カッコ内の数字は段階

(䈉者作成)

注）算術平均值と標準偏差値の倍数との和・差によって段階をつけたので，-11，-12，-15のようにな る場合もある。

18 の 15 学区域であり, 中央・11は銀座, 新宿・35 は神楽坂，千代田・15は丸の内・大手町，中央・14 は築地, 台東・11は上野などのように東京の都心部 を形成している地域を含む学区域である. 上記以外 の都心 3 区といわれる千代田・中央・港区の諸学区 域においても，その発生交通率は平均值である 0.91 より低く，-1の段階が多くみられる。したがって， 都心部はだいたい発生交通率の低い地域であるよう
に思われる。

この発生交通率の地域差を生ぜしめる原因を分析 するため東京都で産業別人口のうち多くの比率を占 める製造業，卸・小売業，サービス業，公務・自由 業，無業者の 5 種死取り上げ，これらの産業別の発 生交通率を各学区域について求め，さらに各々の算 術平均值と標準偏差值によって前記と同じ方法で段 階をつ忖，各学区域の発生交通率の段階と比較検討 
をしてみた，第 2 表は発生交通率の段階が $+3,+2$, - $3,-2$ の学区域に抢ける産業別の発生交通率と その段階を示したものである.その結果, 製造業, 卸・ 小売業, サービス業, 公務・自由業者の発生交通率の 段階の $(+) ，($ 一)の符号と各学区域全体のそれとは 一致しないが，無業者の符号とは一致する。しかも， 無業者の人口数は各学区域での人口の過半数を占め ている．したがうて，無業者の発生交通率の高低が 発生交通率の地域差を左右しているものと思われる.

\section{2）発生交通目的の地域性己都市構成}

地域はそれぞれの都市構成によって発生交通の性 格を異にしていると思われる．商業地域，工業地域， 住宅地域といわれるような地域はそれぞれ発生交通 の目的が異なるはずである。そこで発生交通目的の 地域性走分析し，それと都市構成との関係を考察し てみた。

i）発生交通目的の地域性 85 学区域の調査票 から交通目的を読みとり，学区域別に集計し，各交



第 4 図 東京都区部の被調查学区域における発生交通目的形態 拉よび有業者・無業者の最多発生交通目的 
第 3 表 東京都区部の被調査学区域における産業別の最多発生交通目的と土地利用（昭 33 和年）

\begin{tabular}{|c|c|c|c|c|c|c|c|c|c|c|c|c|c|c|c|c|c|}
\hline \multirow[b]{2}{*}{$\begin{array}{c}\text { 学区域 } \\
\text { 番号 }\end{array}$} & \multicolumn{2}{|c|}{ 有 } & \multicolumn{3}{|l|}{ 業 } & \multirow[b]{2}{*}{$\begin{array}{l}\text { 無 } \\
\text { 業 } \\
\text { 者 }\end{array}$} & \multicolumn{2}{|c|}{ 土地利用 } & \multirow{2}{*}{$\begin{array}{l}\text { 産業・地 } \\
\text { 利用 }\end{array}$} & \multicolumn{2}{|c|}{ 有 } & \multicolumn{3}{|l|}{ 業 } & \multirow[b]{2}{*}{$\begin{array}{l}\text { 無 } \\
\text { 業 } \\
\text { 者 }\end{array}$} & \multicolumn{2}{|c|}{ 土地利用 } \\
\hline & $\begin{array}{l}\text { 製 } \\
\text { 造 }\end{array}$ & $\begin{array}{l}\text { 筤 } \\
\text { 亦 } \\
\text { 売 }\end{array}$ & $\begin{array}{l}\text { サ } \\
1 \\
\text { ビ } \\
\text { ス }\end{array}$ & $\begin{array}{l}\text { 蓩 } \\
\text { 鼻 } \\
\text { 由 }\end{array}$ & $\begin{array}{l}\text { 有全 } \\
\text { 業 } \\
\text { 者体 }\end{array}$ & & $\begin{array}{l}\text { 家積 } \\
\text { 屋に } \\
\text { 床よ } \\
\text { 面る }\end{array}$ & \begin{tabular}{l||} 
都図 \\
市に \\
詁よ \\
画る
\end{tabular} & & $\begin{array}{l}\text { 製 } \\
\text { 造 }\end{array}$ & 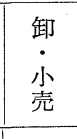 & $\begin{array}{l}\text { サ } \\
1 \\
\text { ビ } \\
\text { ス }\end{array}$ & \begin{tabular}{|c|} 
公 \\
務 \\
$\dot{1}$ \\
自 \\
由 \\
\end{tabular} & $\begin{array}{l}\text { 有全 } \\
\text { 業 } \\
\text { 者体 }\end{array}$ & & $\begin{array}{l}\text { 家積 } \\
\text { 屋に } \\
\text { 床よ } \\
\text { 面る }\end{array}$ & $\begin{array}{l}\text { 都図 } \\
\text { 市に } \\
\text { 計よ } \\
\text { 画る }\end{array}$ \\
\hline 千代田 $\cdot 3$ & B & F & B & $\mathrm{B}$ & B & A & ahd & & 世田谷· 2 & $\mathrm{~B}$ & B & $\mathrm{F}$ & B & B & $\mathrm{C}$ & $\mathrm{a}$ & \\
\hline 6 & F & $\mathrm{F}$ & $\mathrm{F}$ & & $\mathrm{F}$ & $\mathrm{C}$ & ched & & 8 & B & $B \cdot G$ & B & B & B & $\mathrm{A}$ & a & \\
\hline 9 & $\mathrm{~F}$ & $F \cdot G$ & & $\mathrm{~B}$ & $\mathrm{~F}$ & $\mathrm{C}$ & $\mathrm{cd}$ & & 20 & B & B & B & B & B & I & a & \\
\hline 13 & $\mathrm{~B} \cdot \mathrm{F}$ & $\mathrm{B}$ & & B & B & I & $\mathrm{cd}$ & & 26 & B & & & B & B & $\mathrm{A}$ & a & \\
\hline 15 & $F \cdot G$ & $B \cdot D$ & I & $\mathrm{B}$ & B & A & $\mathrm{d}$ & & 32 & B & B & $B$ & B & B & $\mathrm{A}$ & a & \\
\hline 中 央. 2 & $\mathrm{~F}$ & $\mathrm{~F}$ & $\mathrm{C}$ & $\mathrm{B}$ & $\mathrm{F}$ & $\mathrm{C}$ & dc & & 橴 谷. 11 & B & B & $\mathrm{F}$ & B & B & $\mathrm{C}$ & & 住 宅 \\
\hline 5 & $\mathrm{~F}$ & $\mathrm{~F}$ & & B & $\mathrm{F}$ & A & dc & & 15 & B & $\mathrm{F}$ & $B \cdot F$ & B & $\mathrm{B}$ & $\mathrm{A}$ & & 商 業 \\
\hline 8 & $\mathrm{~F}$ & $\mathrm{~F}$ & I & & $F$ & $\mathrm{~A}$ & e & & 18 & B & $\mathrm{F}$ & B & B & B & A & & 住 宅 \\
\hline 11 & & G & $\mathrm{F}$ & & $\underset{\mathrm{G} \cdot \mathrm{I}}{\mathrm{B} \cdot \mathrm{I}} \cdot \mathrm{F}$ & G & $\mathrm{dc}$ & & 中 野 - 3 & B & B & B & B & B & A & a & \\
\hline 14 & B & B & $F$ & B & $\mathrm{B}$ & $\mathrm{A}$ & adcfe & & 13 & B & $\mathrm{F}$ & B & B & B & $\mathrm{A}$ & a & \\
\hline 16 & $\mathrm{~B} \cdot \mathrm{F}$ & $\mathrm{F}$ & I & B & $B$ & $\mathrm{C}$ & ea & & 14 & $\mathrm{~B}$ & B & B & B & B & $\mathrm{C}$ & adc & \\
\hline 港 $\cdot 11$ & B & $\mathrm{F}$ & F & B & B & $\mathrm{A}$ & ecda & & 杉 並·18 & B & $\mathrm{F}$ & F & B & $\mathrm{F}$ & $\mathrm{A}$ & $\mathrm{ac}$ & \\
\hline 24 & B & $\mathrm{F}$ & B & $\mathrm{B}$ & $B$ & A & a & & 豊 島· 4 & B & $\mathrm{F}$ & $\mathrm{F}$ & B & B & $\mathrm{C}$ & a & \\
\hline 新 宿 $\cdot 4$ & B & $\mathrm{F}$ & I & B & $B$ & $\mathrm{~A}$ & ae & & 北 $\cdot 4$ & B & $\mathrm{F}$ & B & $\mathrm{B}$ & B & $\mathrm{C}$ & a & \\
\hline 7 & B & B & B & B & B & $\mathrm{C}$ & $\mathrm{ac}$ & & 6 & B & $\mathrm{F}$ & F & B & B & $\mathrm{A}$ & $\mathrm{ac}$ & \\
\hline 13 & B & $\mathrm{F}$ & $\mathrm{F}$ & B & B & A & $\mathrm{ac}$ & & 17 & B & $B \cdot F$ & B & B & B & $\mathrm{C}$ & ea & \\
\hline 19 & B & $\mathrm{F}$ & $\mathrm{F}$ & B & B & $\mathrm{C}$ & caf & & 18 & $B$ & $\mathrm{~F}$ & B & B & B & $\mathrm{A}$ & a & \\
\hline 21 & $B \cdot F$ & B & $\mathrm{F}$ & B & $B$ & $\mathrm{C}$ & $\mathrm{ac}$ & & 34 & B & B & F & B & B & $\mathrm{C}$ & $\mathrm{a}$ & \\
\hline 30 & B & $\mathrm{F}$ & $B \cdot D$ & B & B & $\mathrm{C}$ & $\mathrm{ad}$ & & 荒 & B & B & B & B & B & $\mathrm{A}$ & & 工 業 \\
\hline 35 & B & $\mathrm{F}$ & $\mathrm{F}$ & B & $\mathrm{F}$ & $\mathrm{C}$ & acd & & 11 & $\mathrm{~B}$ & $\mathrm{~F}$ & B & $B$ & $\mathrm{~F}$ & $\mathrm{~A}$ & & 工 業 \\
\hline 36 & $\mathrm{~F}$ & $\mathrm{~F}$ & $\mathrm{~F}$ & B & $\mathrm{F}$ & $\mathrm{C}$ & $\mathrm{ac}$ & & 板 橋. 1 & B & B & B & B & B & $\mathrm{C}$ & aec & \\
\hline 文 京. 6 & B & F & I & $\mathrm{B}$ & B & $\mathrm{C}$ & $\mathrm{a}$ & & 13 & $\mathrm{~F}$ & $\mathrm{~F}$ & $\mathrm{~F}$ & B & $\mathrm{B} \cdot \mathrm{F}$ & $\mathrm{A}$ & ea & \\
\hline 10 & B & B & & $\mathrm{B}$ & B & $\mathrm{C}$ & ace & & 20 & B & F & $\mathrm{B} \cdot \mathrm{I}$ & B & B & $\mathrm{C}$ & $a$ & \\
\hline 20 & $\mathrm{~F}$ & F & B & B & B & $\mathrm{C}$ & ach & & 37 & B & $\mathrm{F}$ & $\mathrm{F}$ & B & $\mathrm{F}$ & $\mathrm{C}$ & ac & \\
\hline 台 東. 10 & & $\mathrm{~F}$ & $\mathrm{~F}$ & & F & $\mathrm{A}$ & $\mathrm{ca}$ & & 38 & B & $\mathrm{B} \cdot \mathrm{C} \cdot \mathrm{F}$ & B & B & B & $\mathrm{C}$ & ach & \\
\hline 11 & & B & B & & B & $\mathrm{C}$ & c & & 39 & B & B & B & B & B & $\mathrm{A}$ & $a$ & \\
\hline 21 & $\mathrm{~F}$ & F & $\mathrm{C}$ & B & F & $\mathrm{C}$ & cf & & 練 $\quad$ 馬 $\cdot 9$ & B & B & B & B & B & $\mathrm{A}$ & $a$ & \\
\hline 番 田· 13 & $\mathrm{~B} \cdot \mathrm{F}$ & B & & $\mathrm{E}$ & B & $\mathrm{C}$ & & 工 業 & 12 & B & $\mathrm{F}$ & B & B & B & $\mathrm{C}$ & a & \\
\hline 江 東. 2 & $B$ & $\mathrm{C}$ & B & B & B & $\mathrm{C}$ & ace & & 17 & $\mathrm{~B}$ & B & B & B & B & $\mathrm{A}$ & a & \\
\hline 16 & $B$ & $\mathrm{~B} \cdot \mathrm{C} \cdot \mathrm{F}$ & B & B & B & $\mathrm{C}$ & aec & & 19 & $\mathrm{~F}$ & $\mathrm{~F}$ & & B & $\mathrm{B} \cdot \mathrm{F}$ & $\mathrm{C}$ & $\mathrm{a}$ & \\
\hline 17. & B & $\mathrm{F}$ & $\mathrm{F}$ & B & F & $\mathrm{C}$ & ace & & 30 & $\mathrm{~B}$ & $\mathrm{~F}$ & $\mathrm{~F}$ & B & $\mathrm{B}$ & $\mathrm{C}$ & a & \\
\hline 19 & B & $\mathrm{F}$ & $\mathrm{F}$ & B & B & $\mathrm{C}$ & eha & & 足 立· 14 & B & $\mathrm{B} \cdot \mathrm{C} \cdot \mathrm{F}$ & B & B & $\mathrm{B}$ & $\mathrm{C}$ & & 住 宅 \\
\hline 24 & B & B & B & B & B. & $\mathrm{C}$ & ea & & 16 & B & $\mathrm{F}$ & G & B & B & $\mathrm{C}$ & & 工 業 \\
\hline 品 $川 \cdot 11$ & B & $\mathrm{B}$ & $\mathrm{F}$ & B & B & $\mathrm{A}$ & aec & & 29 & B & B & & $\mathrm{B}$ & $\mathrm{B}$ & $\mathrm{C}$ & & 商 業 \\
\hline 37 & B & B & B & & B & $\mathrm{A} \cdot \mathrm{C} \cdot \mathrm{I}$ & & & 31 & B & B & B & $\mathrm{B}$ & B & $\mathrm{C}$ & & 住 宅 \\
\hline 目 黒 $\cdot 20$ & B & $\mathrm{B}$ & $\mathrm{F}$ & B & B & A & & 住 宅| & 葛 飾 - 7 & $\mathrm{~B}$ & $\mathrm{~F}$ & $\mathrm{~F}$ & B & $\mathrm{B}$ & $\mathrm{C}$ & ae & \\
\hline 大 田 17 & $B$ & $\mathrm{~B} \cdot \mathrm{F}$ & B & B & $B$ & $\mathrm{C}$ & & 住 宅| & 10 & $\mathrm{~B}$ & $\mathrm{~F}$ & & $\mathrm{~B}$ & B & $\mathrm{C}$ & $\mathrm{a}$ & \\
\hline 26 & B & $\mathrm{B}$ & $\mathrm{F}$ & $\mathrm{B}$ & B & $\mathrm{A}$ & & 住 宅 & 31 & B & $B \cdot F$ & B & B & B & $\mathrm{A}$ & ae & \\
\hline 29 & B & $B \cdot F$ & B & B & B & $\mathrm{C}$ & & 住 宅 & 41 & B & $\mathrm{F}$ & $\mathrm{F}$ & B & B & A & ae & \\
\hline 45 & B & F & $\mathrm{F}$ & B & B & $\mathrm{C}$ & & 住 宅 & 江戸川 $\cdot 3$ & B & $\mathrm{B} \cdot \mathrm{F}$ & B & B & B & $\mathrm{C}$ & $\mathrm{a}$ & \\
\hline 46 & B & & & B & B & $\mathrm{A}$ & & 淮工業 & 16 & B & $\mathrm{F}$ & B & $B \cdot D$ & B & $\mathrm{C}$ & ac & \\
\hline 54 & B & I & I & B & B & $\mathrm{A}$ & & 工 業 & $\begin{array}{l}18 \\
30\end{array}$ & $\mathrm{D}$ & $\begin{array}{c}B \cdot F \\
F\end{array}$ & $\mathrm{~B} \cdot \mathrm{F}$ & & B & $\begin{array}{l}\mathrm{C} \\
\mathrm{A}\end{array}$ & ae & \\
\hline & & & & & & & & & 30 & B & $\mathrm{F}$ & B & B & B & A & aec & \\
\hline
\end{tabular}

$\mathrm{A}$ 一通学, B一通勤, C一買物, D一映画その他娛楽, $\mathrm{E}$ 一公用, $\mathrm{F}$ 一仕事, $\mathrm{G}$ 一つきあい, H一病気, I一その他 $\mathrm{a}$ 一住宅, $\mathrm{b}$ 一農家, $\mathrm{c}$ 一商業施設, $\mathrm{d}$ 一業務施設, $\mathrm{e}$ 一工業施設, $\mathrm{f}$ 一娮楽施設, $\mathrm{g}$ 一病院, $\mathrm{h}$ 一学校, $\mathrm{i}$ 一その他 交通目的で同じ欄に二つ以上の記号があるのはそれらが同率であることを示す. 空欄は各交通目的をもった人数が 1 人の 場合である.土地利用で左欄が空欄のところは用途別家屋床面積に関する統計が不備な学区域である。

(筆者作成) 
通目的の比率を求めた。この比率を用いて土井喜久 一の提唱した修正 WEAVER 法を利用し ${ }^{38)}$, 各学区域 の発生交通目的形態を求めた。 そして最多発生交通 目的によって色別したのが第 4 図である.

この図から最多発生交通目的を取り上げると， 「通勤」の学区域が最も多く, 50 学区域党数え, 文 京・豊島・北・板橋・練馬・中野・杉並・世田谷・ 目黒・大田・品川・足立・葛飾の各区のように住宅 の多い区に存在し，一方，商業地の多い千代田・中 央・港・台東・新宿・贸谷区拉よび商業，工業地が 多い墨田・江東・荒川・江戸川区においては「仕 事」「買物」を最多発生交通目的とする学区域が多 く存在するようになり，特に「仕事」を最多発生交 通目的とする 9 学区域のうち 7 学区域が下町の商業 地域といわれる千代田・中央・台東の 3 区に集中し ている。「買物」を最多発生交通目的としている学 区域は 15 を数光，概略的には「通勤」を最多発生交 通目的としている学区域と「仕事」をそれにしてい る学区域の間に点在している。 また，東京の最も中 心的地域と思われる千代田・13・15, 中央・11の学 区域は「つきあい」，あるいは「その他」の目的が最 多発生交通目的になっている.

また，最多発生交通目的が同じである二つの学区 域を取り上げてみると ${ }^{39}$ ，第 2 位の発生交通目的が 異なっている場合が少なくない，そ机は各学区域の 都市構成の美異によって生ずるむのと思われる。し たがって，発生交通目的と都市構成との関係をみる 必要がある。

ii） 発生交通目的形態と産業別人口構成 次に， 産業別による各学区域の最多発生交通目的を調査票 から集計し，そのうち人口数の多い製造業，卸・小
売業，サービス業，公務・自由業者および無業者の 5 種を取り上げると第 3 表の左欄のようになる.

製造業者に执いては江戸川・18を除いては「通 勤」「仕事」，卸・小売業者に打いては中央・11， 江東・2，大田・54の 3 学区域走除いては「通勤」, 「仕事」，公務・自由業者に打いては墨田・13 を除 いては全て「通勤」が最多発生交通目的になってい るしかし，サービス業者に打いては中央・2，台東・ 210 両学区域では「買物」, 足立・16では「つきあ い」，千代田・15，中央・8・16，新宿・4，文京・6， 大田・54の諸学区域では「その他」が最多発生交通 目的になっている。しかし，有業者全体としてみる と全ての学区域に执いて「通勤」あるいは「仕事」の 目的で発生する場合が最多く, しかも有業, 無業 者別でみると 85 学区域全体の「通勤」の発生交通量 $100 \%$ ，「仕事」の場合は $89 \%$ を有業者が占めている. 無業者の発生交通目的については，中央・11の 「つきあい」, 千代田・13の「その他」を除くと「通 学」「買物」が最多発生交通目的となり, さらに有 業, 無業者別にみると, 「通学」の発生交通量のうち $98 \%$ ，「買物」の場合は $85 \%$ を無業者が占めている. したがって，有業者は「通勤」「仕事」を，無業 者は「通学」「買物」在代表的な交通目的としてい るといえる。

iii) 最多発生交通目的と土地利用 有業者の最多 発生交通目的が学区域によって「通勤」と「仕事」 のいずれになるか，無業者のそれが「通学」と「買 物」のいずれになるかはそれぞれの学区域の土地利 用と密接な関係があると思われる。

東京都の町丁別の用途別家屋床面積に関する統 計40)を学区域別に集計し，土井喜久一の方式によっ

38) Doi, K. (1957) : Industrial Structure of Japanese Prefecture, Proc. I. G. U. Reg. Conf. in Japan, 310 $-316$

39）例えば BCAF，BACI のように最多発生交通目的が同じ学区域.

40) 東京都各区税務事務所 (1961)：固定資産税評佂調作成資料経，大藏省管財局 (1961) : 国有財産口座別調 書, 東京都税務課 $(1961)$ : 都有財産表・区有財座表, 東京都教育課 $(1961)$ : 私立学校施設調查書をを利 用した。 
第 4 表 被調查学区域中代表的住宅学区域の通 勤発生交通の卓越度

(昭和 33 年)

\begin{tabular}{|c|c|c|c|}
\hline 学区域番号 & 卓越度 & 学区域番号 & 卓越度 \\
\hline 港 $\cdot 24$ & +1 & - 4 & +2 \\
\hline 文 京・ 6 & +1 & 18 & +2 \\
\hline 品 $川 \cdot 37$ & +2 & 34 & +2 \\
\hline 世田谷・ 2 & +1 & 板 橋・ 20 & +1 \\
\hline 8 & +1 & 39 & +2 \\
\hline 20 & +2 & 練 馬・9 & +1 \\
\hline 26 & +2 & 12 & +1 \\
\hline 32 & +3 & 17 & +1 \\
\hline 中 野 - 3 & +2 & 30 & +1 \\
\hline 13 & -1 & 葛 飾・10 & -1 \\
\hline 豊 島・ 4 & +1 & 江戸川・ 3 & -1 \\
\hline
\end{tabular}

て用途記号を組合せ土地利用を学区域別に設定した (第 3 表右闌)。それと有業，無業者の最多発生交通 目的との関係を考察すると次の上うなことが明らか になった。

有業者の最多発生交通目的が「通勤」である学区 域は 69 を数えるが，そのうち 57 学区域の土地利用 は住宅が第 1 位，または第 2 位であるか，あるいは都 市計画図による住宅地域がである ${ }^{41)}$ ，有業者が通勤 するということは居住地と職場が分離している場合 に生じ，通勤すべき職場が発生する学区域内に存在 するか，学区域外に存在するかいずれかである．学 区域内に職場であるべき施設がほとんど存在しない と思われる学区域の「通勤」の卓越度 ${ }^{42) を み る と ， ~}$ それがかなり高いことがわかる(第 4 表)。さらに， 世田谷・2, 江戸川・3 の両学区域を除いては無業者 の最多発生交通目的を越えて，発生交通目的形態に 打いて第 1 位の目的に「通勤」がなっている．有業 者の最多発生交通目的が「通勤」で，住宅以外の施
設の多い残りの 12 学区域，すなわち，千代田・13・

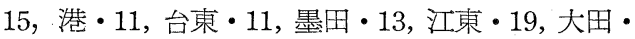
$46 \cdot 54 ＼mathrm{~ 沵 谷 ・ ~} 15 ＼mathrm{~ ， 荒 川 ・ 4 ， 足 立 ・ 16 ・ 29 に 打 い ~}$ ては，大田・46，濯谷・ $15 ，$ 荒川・4，足立・16の 4 学区域を除いていずれも「通勤」以外の目的が発 生交通目的形態の第 1 位になっている。したがって， 住宅地域に执いては最多発生交通目的はだいたい 「通勤」であるといいうる。

有業者の最多発生交通目的が「仕事」である学区 域については 13 学区域を数えるが，「仕事」老目的 とする発生交通は居住地が職場と一致している場合， すなわち，自家労働者が多い地域にみられると思わ れる.この学区域の土地利用をみると，千代田・6・ 9 ，中央・ 2 • 5 の 4 学区域の土地利用は商業的・業 務的施設が大部分であり，また都心部に位置する学 区域でもある。中央・ 8 , 荒川・11 は工業的施設が多 く，台東・ 10，新宿・ $35 \cdot 36 ，$ 杉並・ 18 ，板橋 $\cdot 37$ の 5 学区域においては住宅と商業的施設が混在して おり, 江東・17 では住宅・商業的・工業的施設の 3 者 が混在し，台東・21 では商業的・娛楽的施設が多い. こうした商業，工業，準工業，業務地域においては そこに居住している有業者は「仕事」の交通目的を 最も多く発生するものと思われる。また，そのうち 都心部に位置する千代田・6・9，中央・2・5・8 の 5 学区域においては有業者の最多発生交通目的であ る「仕事」が発生交通目的形態のうちでも最多の目 的になっている.しかし，最も都心的な業務地域と 思われる千代田・13・15 の両学区域ではそこに居 住する有業者は住宅地域と同様に「通勤」を最多の 目的としている.

41）用途別家屋床面積の統計が不備な墨田・大田・目黒・橴谷・足立・荒川の 6 区については東京都建設局 (1958) : 東京都市計画用途別地域図によって土地利用を示す.

42）通勤発生交通量の各学区域における比率の 85 学区域の算術平均値 $(\bar{x})$ は 23.4 , 標準偏差值 $(\sigma)$ は 8.0 である。これを用いて, 各学域の通勤発生交通量の比率を $x$ とすると, $\bar{x} \leqq x<\bar{x}+\sigma \cdots \cdots+1, \bar{x}+\sigma \leqq x<\bar{x}$ $+2 \sigma \cdots \cdots+2, \bar{x}+2 \sigma \leqq x<\bar{x}+3 \sigma \cdots \cdots+3, \bar{x}>x \geqq \bar{x}-\sigma \cdots \cdots-1$ のように段階をつけ，その符号と数字を 卓越度と名付けた。 $+3,+2$ の卓越度をもつ学区域は「通勤」の発生交通の点で他の学区域よりきわめて 卓越していることを意味する. 
無業者の最多発生交通目的は「通学」と「買物」

であるが，「通学」を最多とする学区域は 33 を数え， そのうち土地利用の第 $1 ， 2$ 位を住宅が占めている か，都市計画図で住宅地域としている学区域は 24 を数える。したがって，住宅地域に揖ける無業者は 「通学」を最も多く発生目的としてもつように考え られる。しかし，住宅以外の施設がほとんどみられ
ぬような学区域において,「買物」を最多発生交通目 的としているものもあり ${ }^{43)}$ ，この目的の場合は土地 利用との関係は「通勤」，「仕事」ほど明確ではない。

「買物」はその発生交通量の $59.3 \%$ が発生した学 区域内に目的地をもち，第 5 図からも明らかなよう に発生した学区域の多へ発生するものが少ない。こ れは日常的買物が多く，しかもそれを果たす施設が

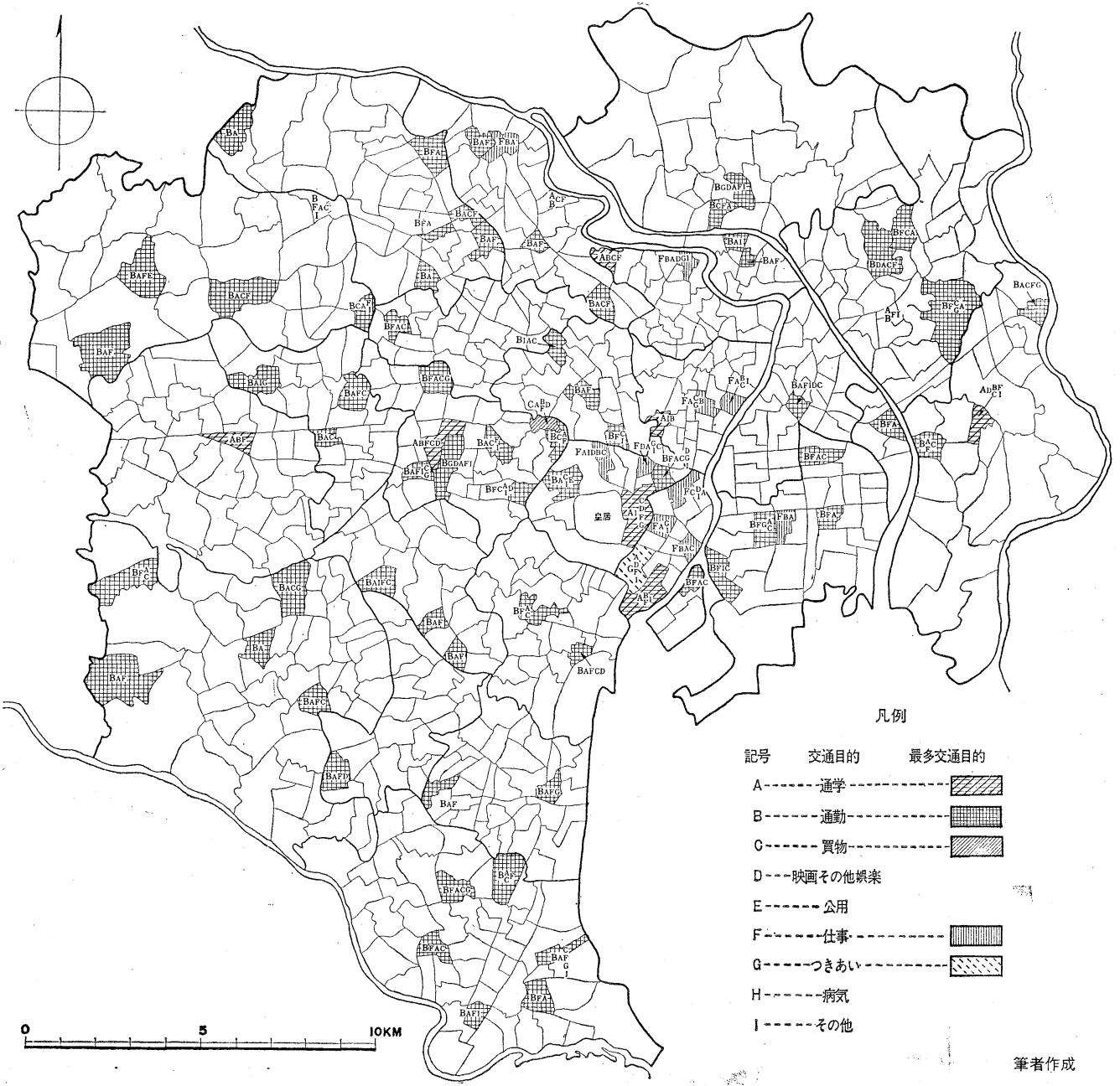

第 5 図 東京都区部の被調查学区域にお括り学区域への発生交通目的形態

43）例えば文京・ 6 ，世田谷・2，豊島・4，北・4・34，板橋・20，練馬・12・19・30，葛飾・10，江戸川・3 の 11 学区域. 


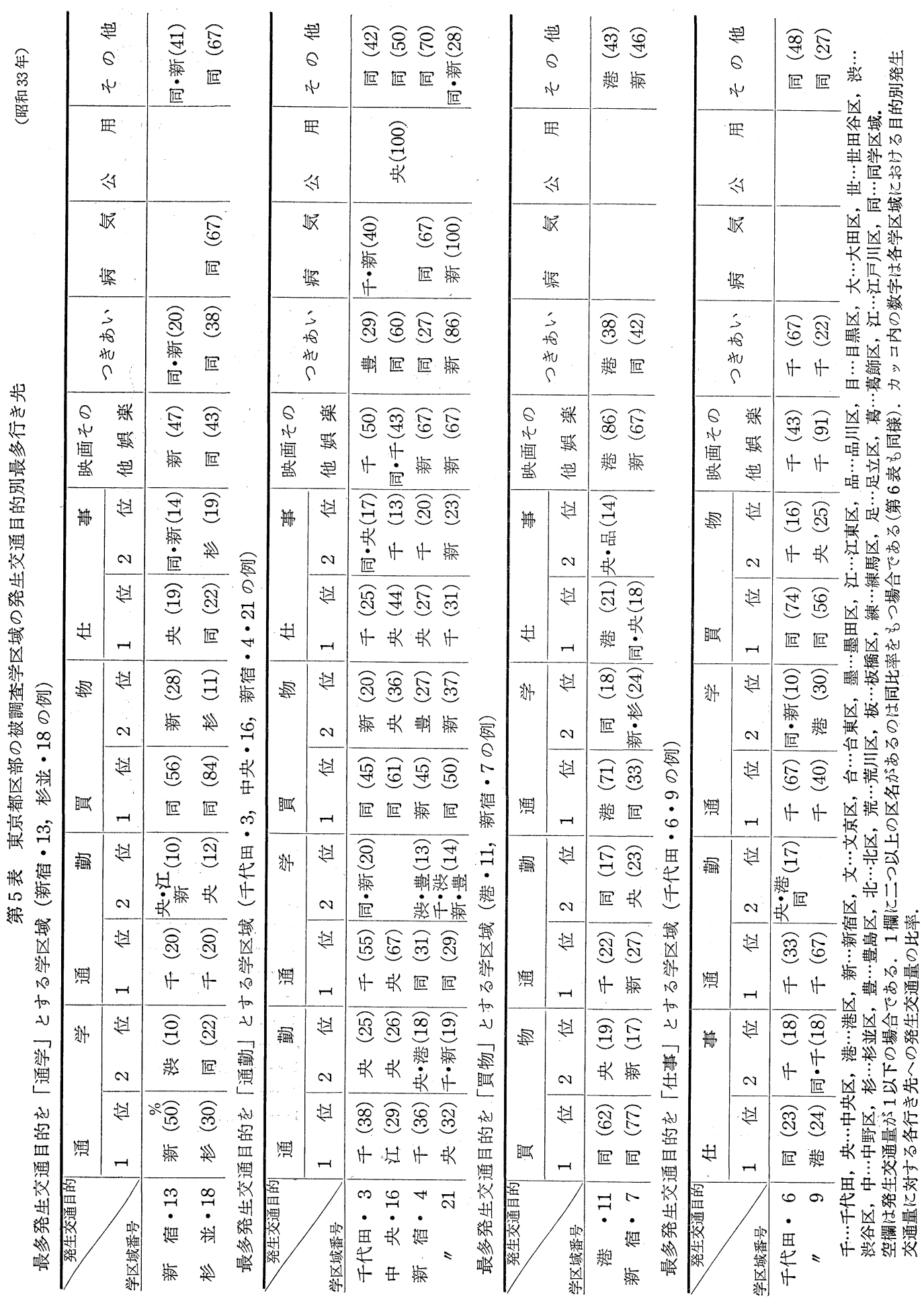




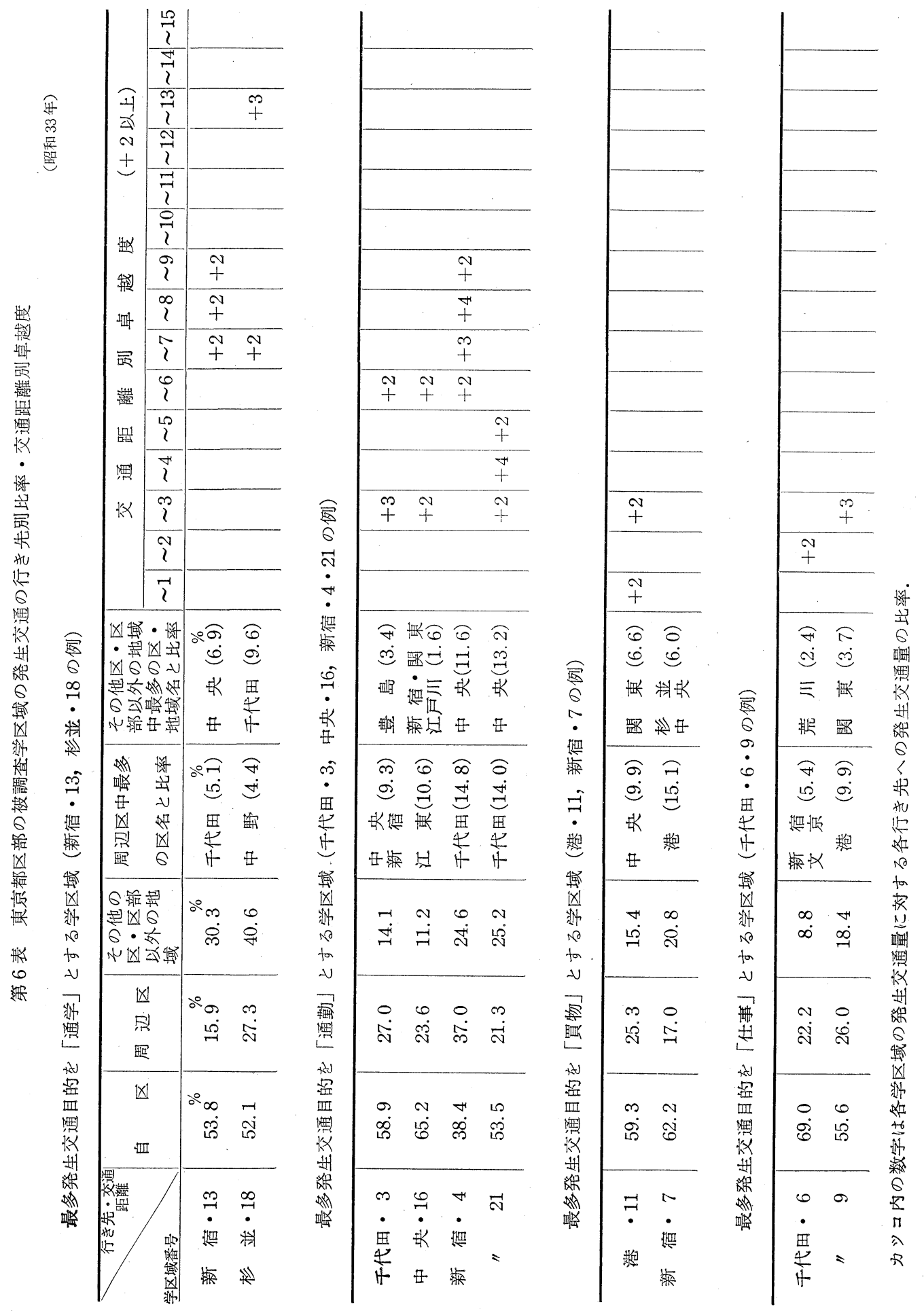


発生した学区域内に存在しているためである。した がって,「買物」が無業者の最多発生交通目的になる 条件として，発生した学区域と同じ学区域内におけ る商業的施設の存在が問題になる. 用途別家屋床面 積が判明している学区域において買物を無業者の最 多発生交通目的としている 40 学区域のうち，20学 区域は商業的施設の多いことでもそのことは明らか であるが，その施設のきわめて少ない上記の 11 学 区域のようにわずかな商業的施設を利用して買物交 通が発生し，最多交通目的となる場合ある。したが って，無業者の場合に抽いて，有業者の場合のよ うに最多発生交通目的と土地利用との間にはそれほ ど明確な関係はみい出されない。

\section{IV. 発生交通の指向性}

次に，前述したような種々の最多発生交通目的を もった地域はどの方向へ，また，どの地域に向って 交通を発生させているか，すなわち各学区域におけ る発生交通の指向性の特色を明らかにする.

第 $5 ， 6$ 表はそのために次の点についてまとめて 作成した表の一例である。すなわち，(1)交通目的別 にどの地域に向って最も多く発生したか，つまり， 交通目的別行き先第 1 位の地域 ${ }^{44)}$ 調べる. その際, 「通学」, 「通勤」,「買物」,「仕事」の 4 種の交通目 的に関してはその発生交通量が多いので第 1 位のみ
でなく，第 2 位の行き先についても調べる. (2)全体 としてどの地域に向って多く発生したかを，(イ)その 学区域が存在してる自区，(听その区に隣接する周辺

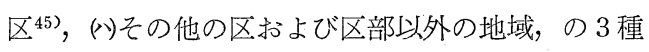
にまとめて調べる，さらに，(3)一般に発生交通の指 向性については，近距離，すなわち自区のような地 域へは多くの交通が発生し，距離が遠くなるにつれ て，すなわち周辺区，それより外辺への地域となる に従って少なくなることが知られているが，各学区 域について交通距離による発生交通の派減がどのよ うになっているかを調べる。この場合, 各交通距離 別の発生交通量の比率の平均值と標準偏差值を求め, 両者の和によって卓越度に決定し(第 7 表), それの +2 以上である交通距離のみを問題とすることにし た ${ }^{46)}$.

\section{1）通学の指向性}

最初に最多発生交通目的が「通学」である新宿・ 13 , 杉並・18 の両学区域についてみると, 通学先は 自区执よび同学区域が多く，それ以外の地域へ向う ものがきわめて少ない. 新宿・13 学区域では涉谷 区に通学するものがわずか $10 \%$ あるる.これは 85 学区域についても通学先の第 1 位の地域を自区とす るものは 46, 同学区域とするもの 34 , それ以外の地 域とするもの 10 であり47)，大部分自区および同学 区域へ通学している. それ以外の地域へ通学すると

44）一応，行政上の区を単位地域としてとった。

45）各区における周辺区は次のとうりである.

千代田区一中央・台東・文京・新宿・港区，中央区一千代田・台東・墨田・江東 - 港区，港区一千代 田・中央・新宿・品川・目黒・渋谷区, 新宿区一千代田・港・文京・渋谷・中野・豊島区, 文京区一千代 田・新宿・台東・北・筧川・豊島区，台東区一千代田・中央・文京・眰田・荒川区，墨田区一中央・台 東・江東・荒川・足立・葛飾・江戸川区，江東区一中央・畦田・江戸川区，品川区一港・大田・目黒・泚 谷区, 大田区一品川・目黒・世田谷区，目黒区一港・品川・大田・湝谷・世田谷区，世田谷区一大田・目

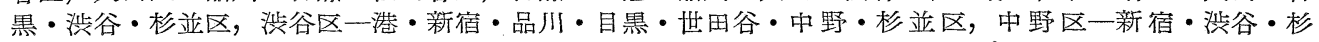
並・豊島・練馬区，杉並区一洗谷・世田谷・中野・練馬区，豊島区一新宿・文京 - 中野・北・板橋 - 練馬 区，荒川区一文京・台東・悬田 - 北・足立区，北区一文京・豊島・荒川・板橋 - 足立区，板橋区一豊島・ 北・練馬区, 練馬区一中野・杉並・豊島・板橋区, 足立区一墨田・荒川・北・葛飾区, 葛飾区一墨田 - 足 立・江戸川区，江戸川区一江東・畺田・葛飾区

46）各学区域の交通距離別の比率の計算をし，交通距離別に学区域の平均值を算出したが，それを一応交通 距離にともなら発生交通の瓝減の基準として考えた。

47）数を合計しても 85 にならないのは，第 1 位としている地域を二つもつ学区域があるからである. 


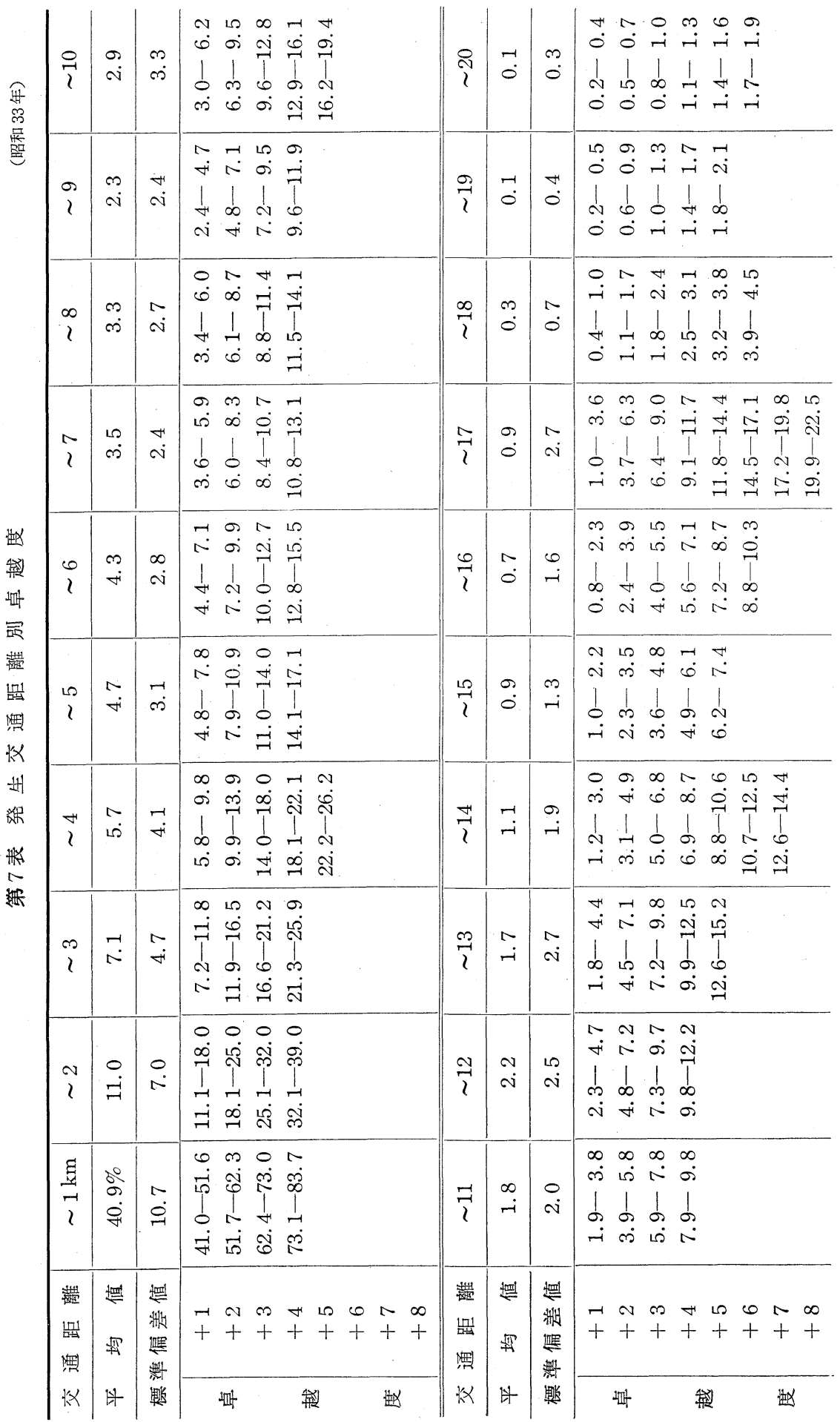


第 8 表 東京都区部の被調查学区域の通学の中学・高校・大学生別最多行き先と学区制との関係（一例）

(昭和 33 年)

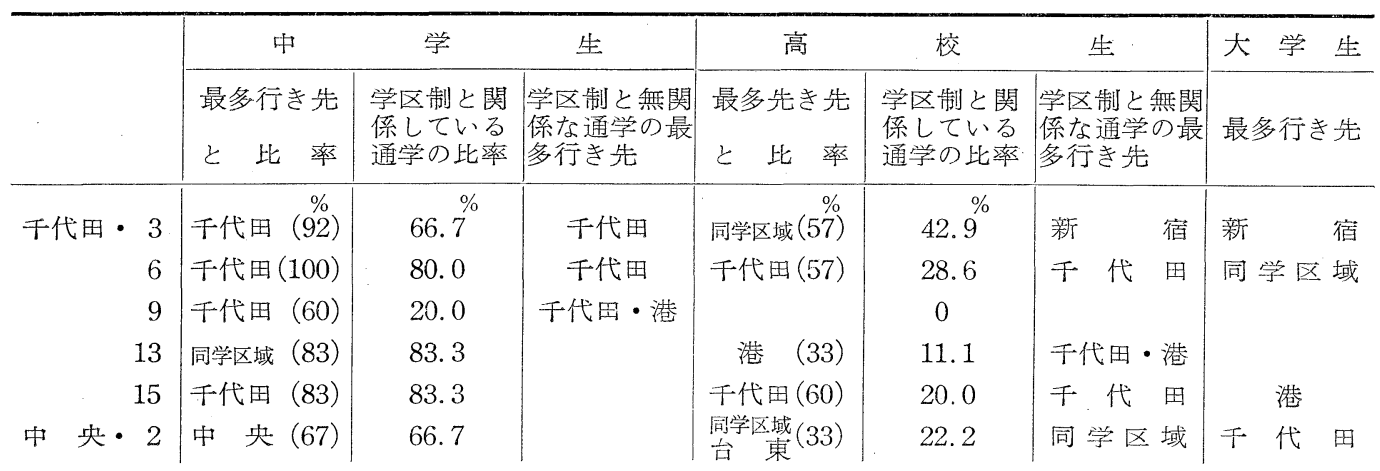

しても上記の新宿・13のように周辺区へ発生する 場合が多い. 第 2 位の地域を 85 学区域についてみ ると，自区，同学区域以外を通学先とする数は 107 のうちで 76 でかなり多くなっているが, 周辺区を通 学先としているものも多く，そのうち 57 を数える。

さらにその内容を詳しく分析してみると，第 8 表 のように，中学生の場合行き先の第 1 位の地域を同 学区域抢よび自区としているものが大部分を占め, 81 を数え，しか子第 1 位の行き先の占める比率は高 校生，大学生に比して著しく高く，そして大部分近 距離の地域へ指向している.このことは学区制の結 果であると考えられるので，中学学区制に関係する 通学を摘出すると中学生の通学交通量の $71.6 \%$ に なる.すなわち，中学生の大部分は居住地を含む中 学学区域の公立中学校へ通学することが明らかであ る ${ }^{48)}$. この学区制に無関係な通学の行き先の第 1 位. をみると，自区としているものが 30 , 周辺区として いるのが 7，その他の地域としているのが 7 を数え， この場合でもやはり近距離への指向が強いといえる.

高校生の場合は中学生の場合とはかなり異なり， 同学区域を行き先の第 1 位としているものがわずか
6 のみであるが，自区打よび周辺区とするものが 40 および 51 を数元, 通学の距離は長く, 指向する地域 は居住地とかなり離れる。またその第 1 位の行き先 の占める比率も小さく，特定地域へ指向するのでは なく種々の地域への分散指向する傾向がみられる. それは高校の学区制に関係をもつ通学を摘出してみ ても中学生の場合とは比較にならぬぼと少なく，85 学区域全体で $18.4 \%$ 占めるにすぎない49)，それ を除いた通学においては，行き先の第 1 位を自区と しているものが 28 ，周辺区としているものが 48 ，そ の他の地域としているのが 22 であり，かなり遠距 離への指向が強い。

大学生の場合では，行き先の第 1 位を自区とする ぬのが 4，周辺区とするもの 18，その他の地域とす るものが 47 であり，その他の地域へ通学するもの が非常に多く，特に千代田区への指向するものがか なりの数にのぼっている。この場合，大学生の発生 交通量が少ないので明確なことは述べられないが， 前記の二者の場合よりさらに遠距離への指向が強い ように思える。

\section{2）通勤の指向性}

48）東京都の調查によれば公立中学校生徒数は全中学生徒数の $84.8 \%$ である. 東京都（1961）: 学校基本調 查報告.

49）東京都の調查によれば全日制普通課程高校生徒数は全高校生徒数の $20 \%$ ある。 
第 9 表 東京都区部の被調查学区域の通勤の指向類型

\begin{tabular}{|c|c|c|}
\hline \multicolumn{2}{|c|}{ 類 型 } & \multirow{2}{*}{ 各 類 型に 属 す る 学 区 域 名 } \\
\hline 第 1 位 & 第 2 位. & \\
\hline 自 区 & 自 区 & 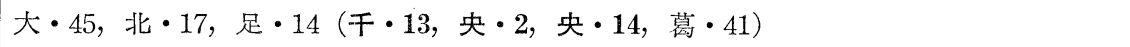 \\
\hline 自 区 & 周辺区 & 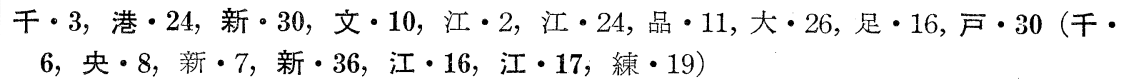 \\
\hline 自 区 & 他 区 & 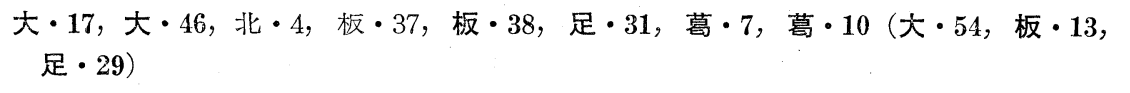 \\
\hline 周辺区 & 自 区 & 央・16，文・6，練・17，戸・16（港・11，江・19） \\
\hline 周辺区 & 周辺区 & 新・ 4 ，新・ $21 ，$ 文 $\cdot 20 ，$ 葛・ $31 （$ 新 $\cdot 13 ，$ 新 $\cdot 19 ）$ \\
\hline 他 区 & 自区 & 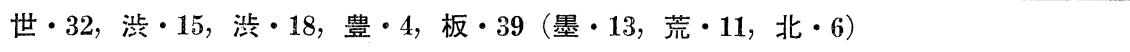 \\
\hline 他 区 & 周辺区 & 世・8，北・34，練・30（新・35，戸・3） \\
\hline 他 区 & 他 区 & 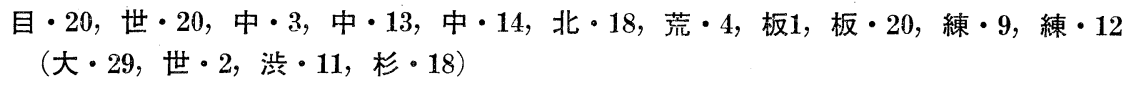 \\
\hline 自 区 & & 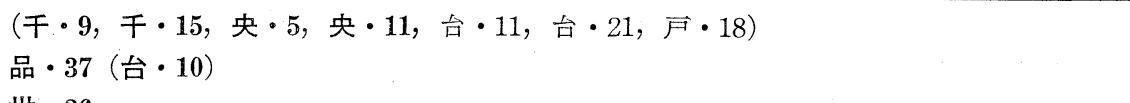 \\
\hline 他 区 & & 世・26 \\
\hline
\end{tabular}

通勤の指问性について最多発生交通目的を「通 勤」とする 50 学区域支例にとってみると，第 1 位 に自区，周辺区，その他の区・区部以外の地域，第 2 位にも同項目をとる学区域があるが，この第 1 位 と第 2 位との地域の組合せによって通勤の指向類型 を想定してみた。それぞれの類型に属する学区域は 第 9 表のとうりである。通学の場合とは異なり，自 区以外の地域へ通勤するものが多くなっている.

千代田・3，中央・16，港・24のような都心部に 位置する学区域においては自区および周辺へ指向す る通勤が大部分を占めて㧍り，最多発生交通目的を 通勤以外とする都心部の学区域に扎いてこのこと は同様である。一方，都心部から最为離れた東京都 区部の内縁部に位置する学区域に掞いては，周辺区 およびその他の区への通勤が多く発生し，特に後者 の地域へ通勤する場合が多く，これは他の交通目的 にはみられない形態である。その典型的な地域であ る通勤の指向類型のうち第 1 位，第 2 位の行き先き
をともに他区とする 11 学区域はすべて千代田・中 央・港の 3 区への通勤がかなりの比重を占めている ことから明らかなように，区部内縁部の学区域にお ける他区への通勤は都心部への指向が強い。しかし， 内縁部の学区域の $ち$ で歹大田・45, 北・17，足 立・14，葛飾・41においては大部分を自区へ通勤す るという場合もあり，自区のみで独立した通勤圈を もつ学区域がある. また，大田・26, 葛飾・31, 江 戸川・16のように都心部ではない周辺区への通勤 がかなり多い学区域もある。

こうした内縁部と都心部の中間に位置する墨田， 台東, 江宋, 文京, 新宿, 涉谷, 品川などの区の学 区域に竌いては周辺区への通勤がかなり多く，その うら区部西部の学区域においては都心部への通勤が 多く，杗部の学区域においては少ない。

以上のことから，都心部の地域においては自区へ の通勤が多く，都心部と内縁部との中間地域におい ては，区部西部では都心部への通勤の指向が強く， 
東部では弱く，江東，墨田，足立，葛飾，江戸川の 5 区，いわゆる江東地域は独立した通勤圈をもつよ うに思われる。内縁部，特に区部西部においては都 心への通勤の指向が強いといえる.

\section{3）買物の指向性}

買物の指向性は通勤の場合とは非常に異なり，最 多発生交通目的に「買物」をとる学区域における第 1 位の行き先は大部分が同学区域であり，その数は 行き先の地域数 84 のうち 75 を占めている。また， 買物の $59.3 \%$ は同学区域へ発生していること在前 述したが，同学区域走行き先の第 1 位としている比 率をみても各学区域とも他の目的の場合と比較して 最大であり，買物交通は四つの主要な交通目的であ る「通学」，「通勤」，「買物」，「仕事」のうち最短の 交通距距離をもつように思われる.

第 2 位の行き先については行き先の地域数 83 の うち同学区域扎よび自区を行き先としてるぬのが 57 で，やはり大部分近距離交通である．残りの行き 先の地域には核的な地域がみられる。 それは新宿， 中央，豊島，台東，文京，涉谷，葛飾，千代田区で ある、すなわち，新宿区（新宿地区）へは千代田・ 3 , 世田谷・ $2 \cdot 20$ の 3 学区域, 中央区（日本橋, 銀 座）へは千代田・9・15, 港・ 11, 新宿・ 35, 江東・ 19 , 目黒・2006 学区域, 豊島区（池袋）へは新 宿・4，文京・ 6，北・4，板橋・1・13・37・38・39， 練馬・12の9学区域, 台東区（上野，浅草）へは文 京・10・20, 墨田・13 0 3 学区域, 支京区（江戸川 橋）へは台東・ 21 ，涉谷区（涉谷地区）へは世田 谷・8，葛飾区 (新小岩) へは江戸川・16，千代田区 (有楽町) へは足立・16が指向している.したがっ て，千代田区からは新宿，中央区へ，港区からは中 央区へ，新宿区からは豊島，中央区へ，文京区から は豊島，台東区へ，台東区加は文京区へ，江東区 からは中央区へ，墨田区からは台東区へ，世田谷区 からは新宿，䔝谷区へ，板橋，練馬区からは豊島区
へ，江戸川区から葛飾区への買物の指向が強いと思 われる。

\section{4）仕事の指向性}

「仕事」の場合は通学の場合と同様に近距離交通 がかなり多く，第 1 位の行き先をみるとその地域数 103 のうち自区へ発生するものが 70, 第 2 位では 88 のうち 48 起占めている. 千代田・ 6 , 中央・ $2 \cdot 16$ などのような都心部の学区域においては第 1 位，第 2 位ともに自区で占めている場合が多く，都心から 離れるにつれて自区以外の地域へ多く発生するよう になる。しかし，この場合でも千代田，中央，港の 都心区への発生が顕著であり，この区に接する新宿， 台東，文京，品川，江東，涉谷の各区に执いても都 心部への発生が多く, 都心部以外のこれらの区に接 する諸区への発生は少ない、区部の内縁部の学区域 に扔いても都心部への発生は多く, 第 1 位の地域で 自区以外一発生する地域数 33 のうち, その他の区 へ発生するものが 18 であり，そのうち 14 が都心区 である、第 2 位においても 25 のうち 16 が都心区を 行き先としている.したがって，「仕事」の場合は近 距離への指向が強いが，通勤と同様に都心部への指 向孔かなり強いといえる。

このような四つの最多発生交通目的の指向性在綜 合すれば，だいたい発生交通全体の指向性が明らか になる，都心部においては自区，周辺区の比率が非 常に高く，都心部から離れるに従って自区，周辺区 の比率はやはり高いがその值を減じ，その他の区・ 区部以外の地域の比率が增してくる.したがって， 交通距離に拈いてぬ都心部では短距離交通が主であ り，周辺部になるに従ってそれは長くなる。これは 前述したように，都心部への指向が各学区域に执い てかなり多く，特に通勤，仕事の場合顕著であるか らである。したがって，都心部に拈いては都心 3 区 相互の交通が多く，都心部に接する地域に扔いては 他の地域への指向より都心部への指向が強く，さら 
に内縁部においてはかなり距離が離れているにもか かわらず都心部への指向が強い。しかし，都心部と 内縁部の中間の地域に内縁部からの指向がかなり強 い地域があり，目黒，世田谷区から涉谷区，大田区 から品川区，北，板橋，練馬区から豊島区，足立区 から荒川区，江戸川区から江東区へがそれである。 すなわち，内縁部からの発生交通の指向の強い地域 が都心部と，都心部と自地域との中間の地域の二つ あるわけである。この二つの地域を比較すると交通 距離別の卓越度を考慮に大れれば，中間の地域より 都心部への指向の方が強いといえる.

\section{V. 結 語}

配布した調査票から得られた資料に基づいて，都 市構成と関連付けながら都市交通の地域性を量的面 ばかりでなく質的面からも考察するという筆者の課 題のうち，発生交通の地域性，それと都市構成との 関係抢よび発生交通の指向性の 3 点について論述し た。この問題については東京都区部のみならず本邦 の諸都市についてり考察する必要があるが，今回の 報告を一応要約すれば次の諸事項となる。

(1)発生交通量はだいたい地域の居住人口と深い関 係をもつが，居住人口 1 人当たりの発生交通量（発 生交通率）は都心部に低く，内縁部に高い傾向があ
る。それには無業者の発生交通率が大きな影響を与 えている.

(2)発生交通の交通目的は有業者の最多発生交通目 的である「通勤」「仕事」と無業者の最多発生交通 目的である「通学」，「買物」の4 種で大部分が占め られている。

(3)発生交通では住宅地域においては「通学」，「通 勤」，「買物」の3 種の交通目的肪，商業，工業，業 務地域に捛いては「仕事」の交通目的が最も多い.

(4)こ机ら 4 種の交通目的の指向性に执いては，通 学の場合は大部分近距離を主とし，中学生，高校生， 大学生の順に交通距離は長く，中学生の指向性はそ の学区制に最も強く影響圭うけている. 通勤の場合 は，4種の交通目的のうち最長の交通距離をもち， かつ各地域とも都心部への指向か強く，買物の場合 は最短の交通距離で大部分地元へ指向し，仕事の場 合はかなり地元へ指向するが，通勤の場合と同様に 都心部への指向斗かなり強い傾向がある.

\footnotetext{
謝辞 この研究に対し終始御指導をいただいた青 野寿郎名誉教授, 絶えず激励の御言葉と御助言をい ただいた尾留川教授, 山本正三助手をはじめとする 東京教育大学地理学教室の諸先生に深謝の意を表す る. また調查に御協力をいただいた東京都各区小学 校抢よび各種の資料を御提供くださった東京都関係 機関の各位に感謝の意を表する次第である。

(1965年 5 月31日受理)
}

\section{GENERATED AND PULLED TRIPS WITHIN TOKYO (1)}

\section{Takashi OKUNO}

This paper is concerned with the problem on the regional pattern of urban traffic within Tokyo. With regard to this problem; considerable studies have been approached from a quantitative viewpoit, but urban structure seems to have been discussed separately. Thus, the author attempts to clarify the regional pattern of urban traffic from both qualitative and quantitative viewpoits and the relationships between urban traffic and urban structure. More precisely, the purposes of this reports are to clarify the regional of the generated trips from both quantitative viewpoits, the relationships of the trips with population and land uses, and the directions of trips.

A survey was conducted in the following method : first, a questionnaire (Tab.1) was prepared in order 
to search for the actual condition of urban traffic from a qualitative viewpoit; second, eighty-five primary school districts in Tokyo were selected by using the results of the preliminary survey in Shimoda, Shizuoka Pref.; third, fifty questionnaires were distributed to each district by the author.

As a result of analyzing the imformation which was collected from the questionnaires, the following points were made clear :

(1) Number of the generated trips in each district is closely related to the number of inhabitants in the district. The number of generated trips per inhabitant is smallest in the central part of Tokyo, and becomes greater toward peripheries. This difference is primarily due to the difference in the number of generated trips by persons without a job.

(2) In regard to the kind of trip purposes, persons with a job chiefly travel for commuting or working, while persons without a job chiefly travel for attending school or shopping. In residential areas trips for attending schosl, commuting and shopping are mostly generated, while in business, shopping and industrial areas those for working are generated for a most part.

(3) Destination distance of trips for attending school is short, and is longer as the trip person becomes a middle school pupil, a high school student, and a university student in turn. Destination distance of trips for commuting is the longest of all trips. Most of these trips in all districts are directed to the central part of Tokyo, but in eastern areas these trips to the central part are few and there may be a commuting area without strong connection with Tokyo's center. Destination distance of trips for shopping is the shortest of all trips and most of these trips are directed within the same district where they are generated. Trips for working are directed to two areas, that is, the same district where they are generated and the central area of Tokyo. 